\title{
Role of agronomic manipulations in modification of wheat microclimate under central Punjab
}

\author{
Sarabjot Kaur Sandhu* and L. K. Dhaliwal \\ School of Climate Change \& Agricultural Meteorology, Punjab Agricultural University, Ludhiana-141001 \\ (Punjab), INDIA \\ *Corresponding author. E-mail: skchahal@pau.edu \\ Received: March 6, 2016; Revised received: July 30, 2016; Accepted: October 28, 2016
}

\begin{abstract}
Wheat crop is influenced by different microclimatic parameters like solar radiation, canopy temperature etc. Agronomic manipulation like change in row spacing and row direction can be used as a strategy to modify the microclimate of crop. Keeping these facts in view, field trials were conducted during rabi 2012-13 and 2013-14 under two experiments in first experiment wheat varieties HD 2967, PBW 550 and PBW 343 were sown under three row spacing viz. $15 \mathrm{~cm}, 22.5 \mathrm{~cm}$ and $30 \mathrm{~cm}$. In second experiment, wheat varieties HD 2967, PBW 550 and PBW 343 were sown under two row direction viz. North-South $(\mathrm{N}-\mathrm{S})$ and East-West $(\mathrm{E}-\mathrm{W})$. Short wave radiation interception and canopy temperature was recorded under different treatments at 15 days interval. Among different row spacing, short wave radiation interception and canopy temperature was maximum at $30 \mathrm{~cm}$ row spacing $\left(77.7 \%\right.$ and $\left.25.1^{\circ} \mathrm{C}\right)$ followed by $22.5 \mathrm{~cm}\left(75.7 \%\right.$ and $\left.24.2^{\circ} \mathrm{C}\right)$ and $15 \mathrm{~cm}$ row spacing $\left(73.9 \%\right.$ and $\left.23.2^{\circ} \mathrm{C}\right)$, whereas under row directions short wave radiation interception and canopy temperature was more $\left(76.5 \%\right.$ and $\left.23.9^{\circ} \mathrm{C}\right)$ in $\mathrm{E}-\mathrm{W}$ row direction as compared to $\mathrm{N}-\mathrm{S}$ row direction $\left(75 \%\right.$ and $\left.23.2^{\circ} \mathrm{C}\right)$. Relationships were developed between dry matter accumulation and canopy temperature. Polynomial relationships gave significant $R^{2}$ value $(0.66 \& 0.69)$ under different treatments. This two year study indicated that agronomic manipulations play an important role in microclimate modification and canopy temperature significantly influence dry matter accumulation under different crop geometry.
\end{abstract}

Keywords: Canopy temperature, Microclimate, Short wave radiation, Wheat

\section{INTRODUCTION}

Wheat (Triticum aestivum L. Emend Feori and Paul) is the second most important rabi cereal crop in India after rice. It provides 21 per cent of the food calories and 20 per cent of the protein to more than 4.5 billion people in developing countries (Braun et al., 2010). Wheat is the staple food of more than 40 per cent of the human population. In India it is second most important food crop, cultivated extensively in NorthWestern and Central zones. It contributes substantially to the national food security by providing more than 50 per cent of the calories to the people who mainly depend on it. In India, during 2013-14, wheat was grown on 31.30 million hectares with production of 95.80 million tones and per hectare yield of 30.59 quintals. In Punjab, during 2013-2014, it was grown on 35.12 lac hectares with production of 176.20 lac tonnes and per hectare yield of 50.17 quintals (Anonymous, 2014).

Wheat is a photo-insensitive and thermo-sensitive long day plant. Both the start and end of wheat crop season are limited by the onset and end of favourable temperature regimes. Wheat requires cool climate during the early part of its growth. Wheat grain yield and quality are also influenced by temperature regimes during different phases of crop growth. Within the growing season itself, warmer temperature shortens the total crop duration. Higher temperature during early vegetative phase results in sparse tillering, poor vegetative growth and early heading; and during grain filling phase leads to forced maturity (Reddy, 2006). A mean daily temperature of $15-20{ }^{\circ} \mathrm{C}$ is optimum for crop growth, development and flowering of wheat crop. An increase of temperature by $2^{\circ} \mathrm{C}$ in wheat resulted in 15-17 per cent reduction in grain yield (Hundal, 2004). Current estimates indicates that in India alone around 13.5 million hectares of wheat is under heat stress (Joshi et al., 2007).

Climate and weather variability especially temperature significantly affect potential wheat yield under irrigated conditions in Punjab. A better understanding of weather resources can help to increase crop productivity. It will enhance the benefits by minimizing losses due to adverse weather conditions (Virmani, 1994). Temperature, radiation and moisture are basic meteorological parameters of significance to agriculture. Under potential conditions, with adequate moisture and fertility, radiation plays the role of a decisive factor for crop growth and development. Thus, manipulation of radiant energy within a crop field by an appropriate adoption of crop stand geometry, like row orientation and row spacing can provide a means to create 
light saturated conditions for crop canopy for the purpose of efficient harvest of solar energy for agricultural production. Row spacing can provide a physical barrier between the soil and atmosphere and consequently improve heat conditions at the soil surface.

Kumar et al., (2002) observed that the canopy temperature depression (CTD) showed strong positive correlations with organ temperature depression and grain yield of wheat. Organ temperature depression and CTD were positively correlated with LAI and CTD was probably little affected by leaf rolling. They also reported that spike temperature was generally higher than leaf temperature but lower than ambient air temperature. Kingra et al., (2010) reported that during the reproductive phase, all the canopy temperature based indices viz., canopy temperature $(\mathrm{Tc})$, average canopy minus air temperature (Tc-Ta) and summation stress degree days (SDD) showed a negative and significant relationship explaining 71-87 per cent variation in grain yield. These findings signify an ample scope of mid day canopy temperature as a possible tool for monitoring plant water status and grain yield prediction. Keeping in view the importance of agronomic manipulations viz. Row spacing and row orientation in modification of crop microclimate this study was planned.

\section{MATERIALS AND METHODS}

The field experiments on wheat were conducted at the Research Farm, School of Climate Change and Agricultural Meteorology during rabi 2012-13 and 201314. In first experiment wheat varieties HD 2967, PBW 550 and PBW 343 were sown under three row spacing viz. $15 \mathrm{~cm}, 22.5 \mathrm{~cm}$ and $30 \mathrm{~cm}$. In second experiment, wheat varieties HD 2967, PBW 550 and PBW 343 were sown under two row direction viz. North-South (N-S) and East-West (E-W) under irrigated conditions. The crop was raised as per recommendations of Punjab Agricultural University. Short wave radiation was measured with Pyranoalbedometer (Model LOM1084). The incoming and reflected radiation measurements were made 1 meter above the canopy while transmitted radiation was recorded at the base of canopy at 15 days interval. Short wave radiation interception was calculated by using following formulae:

SWR interception $=\stackrel{\text { Incoming radiation }-(\text { Reflected radiation }+ \text { Transmitted radiation })}{ } \times 100$ Incoming radiation

Canopy temperature was measured at 1400 hours with the help of Infrared Thermometer (FLUKE-574) in first and second experiment. The Infrared thermometer was held at $45^{\circ}$ to the horizontal above the canopy so as to look in a downward direction towards the crop surface. Relationships of dry matter accumulation were developed with canopy temperature.

\section{RESULTS AND DISCUSSION}

Short wave radiation interception in different row spacing: Solar radiation is the ultimate source of all the energy for physical and biological processes occurring on earth. All five determinants of crop growth proposed by Charles-Edward (1981), namely light interception, utilization of intercepted light, dry matter loss due to respiration, partitioning of assimilates to economically harvestable parts and duration of crop growth are influenced by the prevailing environmental conditions of radiation and temperature. Grain yield is the product of radiation interception, conversion efficiency of intercepted radiation to dry matter and partitioning (Jarwal and Singh, 1990). Short wave radiation interception in the crop canopy is an important aspect affecting the crop growth and yield. Apart from soil moisture and temperature, radiation received by crop canopy during the crop season is of much concern as it is directly related to dry matter production. Radiation dynamics within the crop significantly contribute to crop yield. Response of crop varieties may or may not be similar in same or different radiation regimes. Carretero et al. (2010) reported that the leaf area together with the angular arrangement of individual leaves determines the amount of radiation that penetrates the canopy and strikes the ground.

The data of short wave radiation (SWR) interception was recorded on 45, 60, 75, 90, 105, 120 and 135 days after sowing in varieties HD 2967, PBW 550 and PBW 343 in different row spacing. SWR interception is presented in Figs. 1 (a-f). Short wave radiation interception varied with leaf area index (LAI). SWR interception was highest during the heading stage almost about 90 days after sowing in all the varieties under different row spacing. SWR interception was highest (77.5 and 77.7 per cent) in $30 \mathrm{~cm}$ row spacing followed by 22.5 $\mathrm{cm}$ row spacing (75.4 and 75.7 per cent) and $15 \mathrm{~cm}$ row spacing (73.7 and 73.9 per cent). Among different varieties, HD 2967 intercepted maximum SWR (73.7 and 73.9) in $15 \mathrm{~cm}$ row spacing followed by PBW 343 (73.4 and 72.0 per cent) and PBW 550 (72.8 and 73.0 per cent) during 2012-13 and 2013-14. Under $30 \mathrm{~cm}$ row spacing, HD 2967 intercepted maximum SWR (77.5 and 77.7 per cent) followed by PBW 343 (76.8 and 77.0 per cent) and was minimum in PBW 550 (74.6 and 75.0 per cent) during 2012-13 and 2013-14 at heading stage. SWR interception decreased gradually 90 days afterwards due to decrease in leaf area of crop. Tompkins et al. (1993) observed that row spacing had a significant influence on the level of solar radiation that penetrated to the base of the crop canopy. The mean daily solar radiation was $1100 \mu \mathrm{mol} /$ $\mathrm{m}^{2} / \mathrm{s}$ within the $36 \mathrm{~cm}$ row spacing canopy, compared with $845 \mu \mathrm{mol} / \mathrm{m}^{2} / \mathrm{s}$ within the $9 \mathrm{~cm}$ row spacing canopy. About 30 per cent more light penetrated to the base of the $36 \mathrm{~cm}$ row spacing canopy.

Short wave radiation interception in different row direction: Solar radiation is one of the important parameter of the climate which provides essential energy 
(a) $\mathrm{HID} 2967$

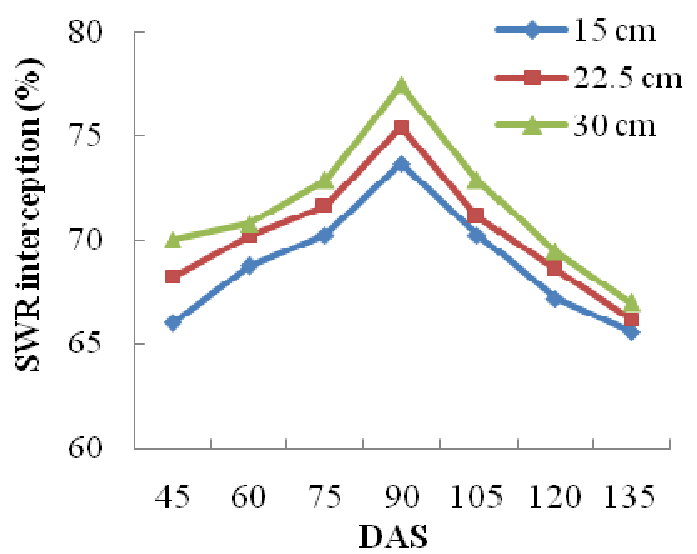

(c) PBW 550

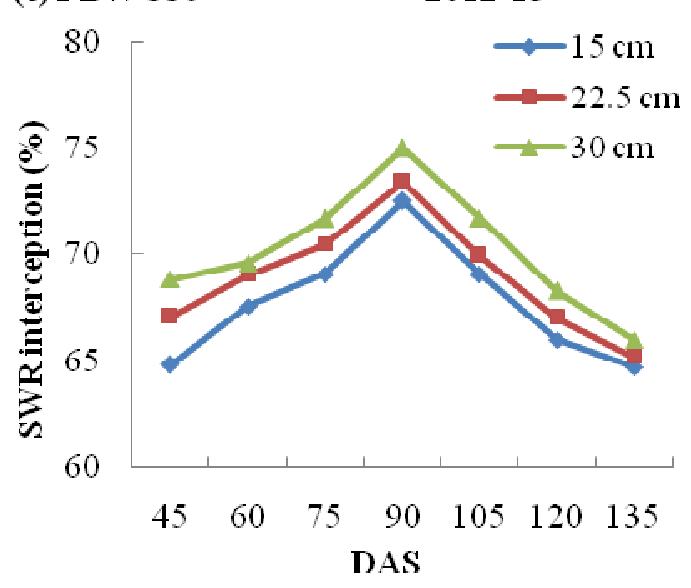

(e) PBW 343

2012-13

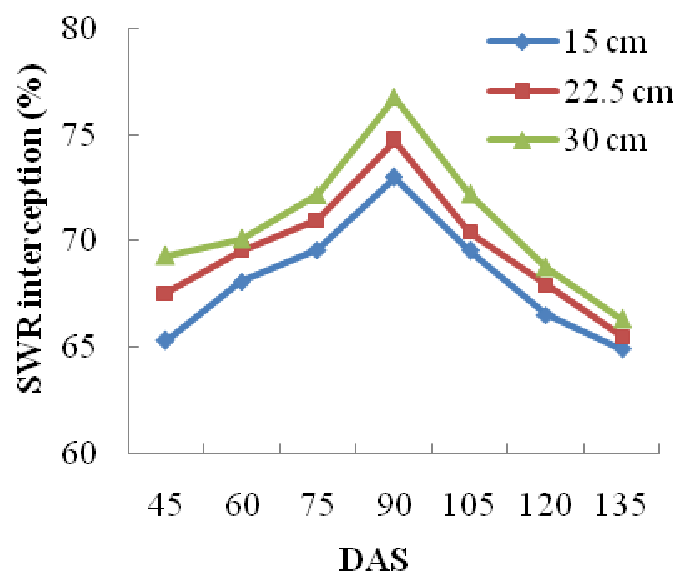

(b) $\mathrm{HD} 2967$

2013-14



(d) PBW 550 2013-14

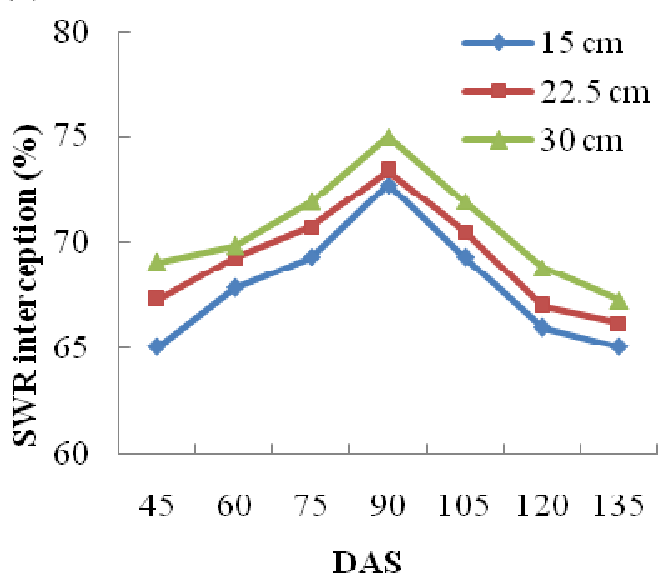

(f) PBW 343

2013-14

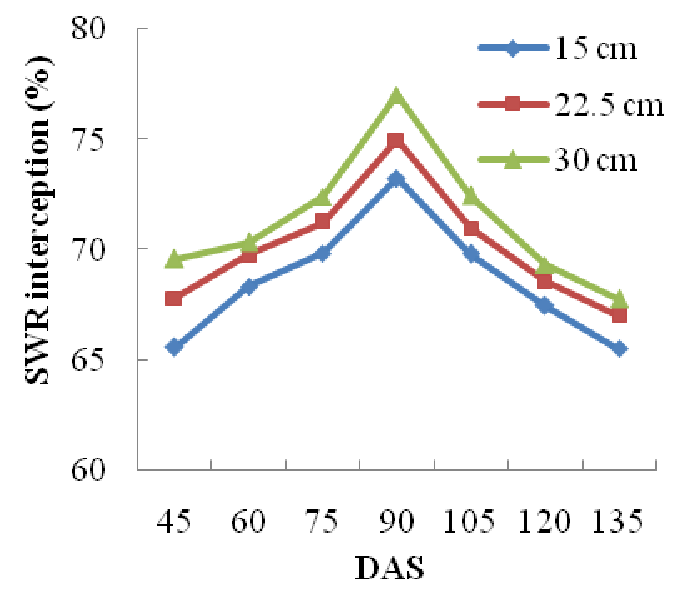

Fig. 1 (a-f). Comparison of mean SWR interception in different row spacing during 2012-13 and 2013-14.

to the crop plants for their growth and development. All the important phenological stages of the crops are generally influenced by quality and quantity of the solar radiation. Solar radiation is very important for plants as it is indispensable to photosynthesis.

Short wave radiation plays an important role in biomass production. Thus apart from biomass production, photosynthates production and its translocation solely depends on radiation regime experienced by the crop at its different phenological stages. Different management practices influence solar radiation interception so knowledge of effects of management practices on solar radiation interception and utilization is necessary to know the physiological basis of improved management 
(a) $\mathrm{HD} 2967$

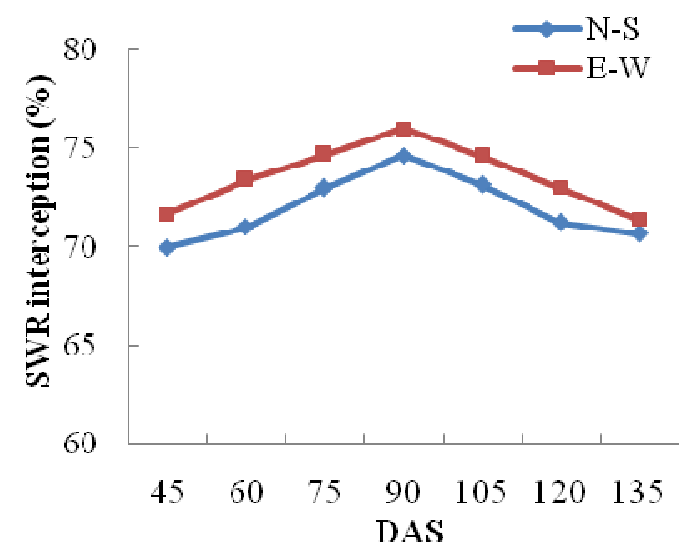

(c) PBW 550

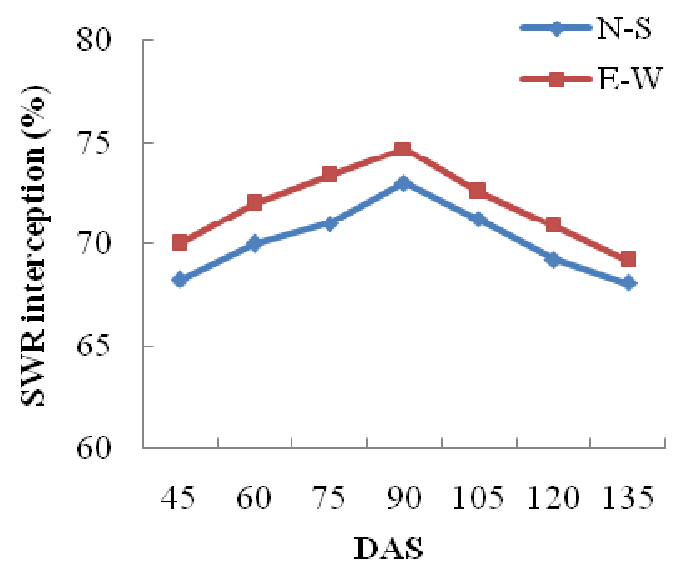

(e) PBW 343

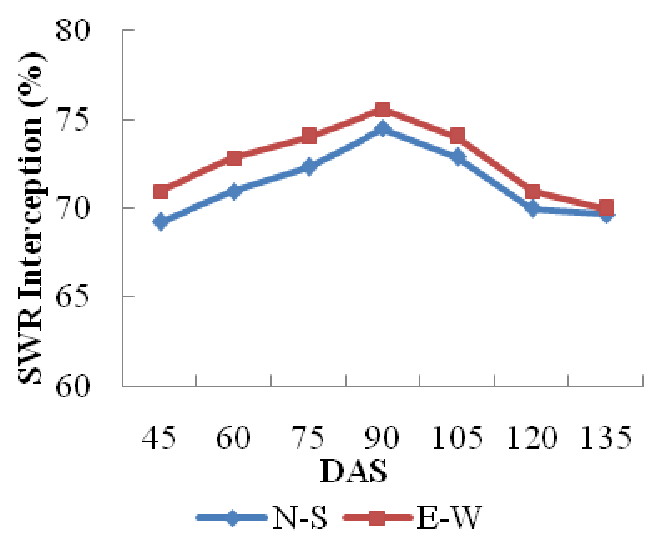

(b) $\mathrm{HD} 2967$

2013-14

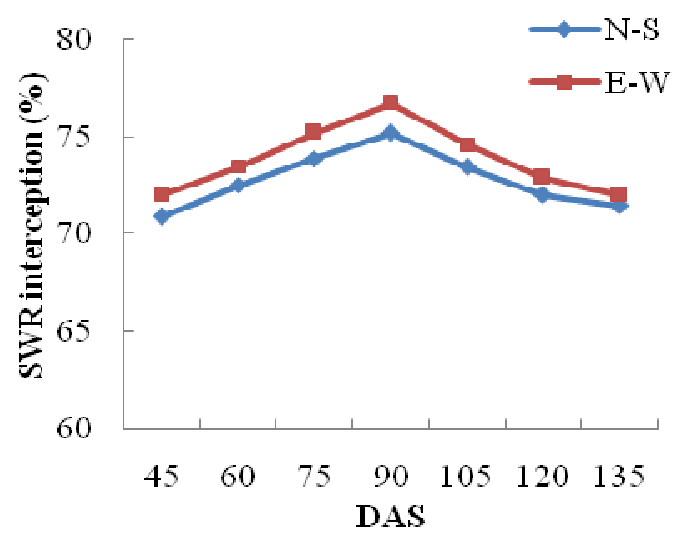

2013-14

(d) PBW 550

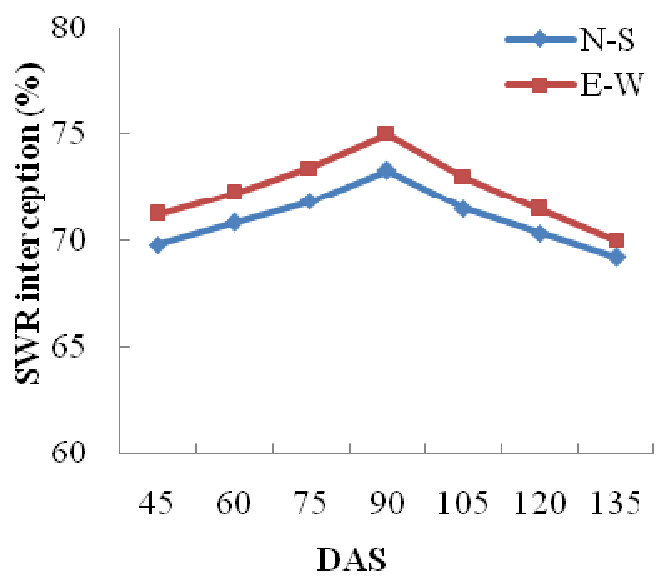

(f) PBW 343

2013-14

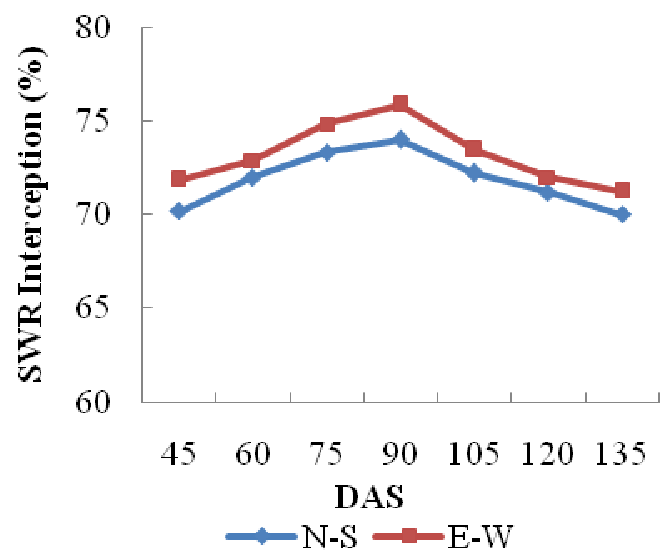

Fig. 2 (a-f): Comparison of mean SWR interception in different row direction during 2012-13 and 201

practices. Short wave radiation interception in the crop canopy is an important aspect affecting the crop growth and yield. So increase in grain yield under E-W row direction can be associated with higher rate of radiation interception. Response of different cultivars to radiation regime may not be similar. The canopy architecture strongly influences the radiation dynamics at any instant in time at any location within crop canopy.
The data of short wave radiation (SWR) interception was recorded on 45, 60, 75, 90, 105, 120 and 135 days after sowing in varieties HD 2967, PBW 550 and PBW 343 in different row direction is presented in Figs. 2 (a -f). Short wave radiation interception varied with leaf area index (LAI). SWR interception was highest during the heading stage almost about 90 days after sowing. Mean SWR interception was higher (76.0 and 76.5 


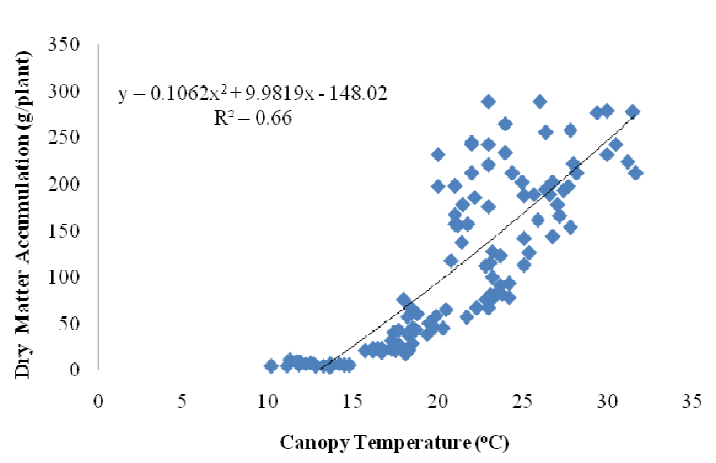

Fig. 3. Relationship between canopy temperature and dry matter accumulation in wheat sown under different row spacing.

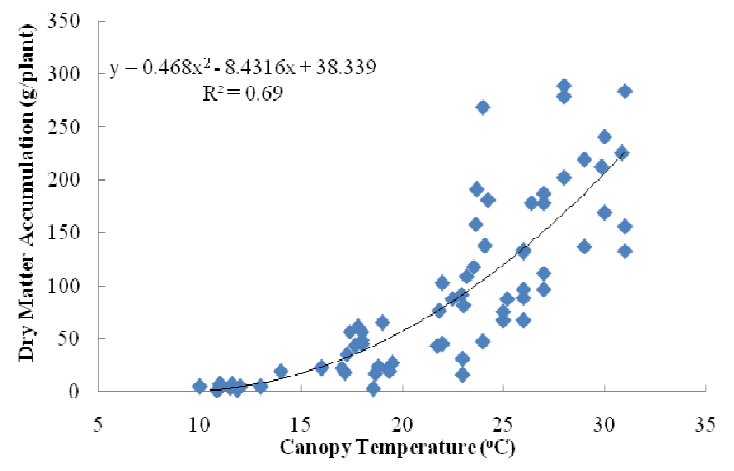

Fig. 4. Relationship between canopy temperature and dry matter accumulation in wheat sown under different row direction.

Table 1. Canopy temperature of wheat sown under different row spacing during 2012-13.

\begin{tabular}{cccccccccc}
\hline & \multicolumn{3}{c}{ HD 2967 } & & \multicolumn{3}{c}{ PBW 550 } & \multicolumn{3}{c}{ PBW 343 } \\
\cline { 2 - 10 } DAS & $\mathbf{1 5} \mathbf{~ c m}$ & $\mathbf{2 2 . 5} \mathbf{~ c m}$ & $\mathbf{3 0} \mathbf{~ c m}$ & $\mathbf{1 5} \mathbf{~ c m}$ & $\mathbf{2 2 . 5} \mathbf{~ c m}$ & $\mathbf{3 0} \mathbf{~ c m}$ & $\mathbf{1 5} \mathbf{~ c m}$ & $\mathbf{2 2 . 5} \mathbf{~ c m}$ & $\mathbf{3 0} \mathbf{~ m}$ \\
\hline 45 & 11.1 & 11.9 & 12.5 & 10.2 & 11.6 & 12.2 & 11.3 & 11.7 & 12.35 \\
60 & 16.2 & 16.5 & 17.7 & 15.7 & 16.2 & 17.5 & 16.7 & 16.7 & 17.2 \\
75 & 18.2 & 19.0 & 20.3 & 17.4 & 17.7 & 18.2 & 18.5 & 18.7 & 19.3 \\
90 & 22.3 & 23.2 & 23.9 & 21.7 & 22.9 & 23.3 & 22.8 & 23.8 & 23.5 \\
105 & 21.5 & 22.2 & 22.8 & 21.2 & 21.8 & 22.3 & 20.8 & 21.4 & 22.2 \\
120 & 26.6 & 26.7 & 27.2 & 25.4 & 26.2 & 26.5 & 26.2 & 26.5 & 27.1 \\
135 & 27.8 & 28.4 & 29.5 & 26.4 & 26.9 & 27.2 & 27.0 & 27.3 & 27.9 \\
\hline
\end{tabular}

Where, DAS: Days after sowing.

Table 2. Canopy temperature of wheat sown under different row spacing during 2013-14.

\begin{tabular}{cccccccccc}
\hline \multirow{2}{*}{ DAS } & \multicolumn{3}{c}{ HD 2967 } & \multicolumn{3}{c}{ PBW 550 } & \multicolumn{3}{c}{ PBW 343 } \\
\cline { 2 - 9 } & $\mathbf{1 5} \mathbf{~ c m}$ & $\mathbf{2 2 . 5} \mathbf{~ c m}$ & $\mathbf{3 0} \mathbf{~ c m}$ & $\mathbf{1 5} \mathbf{~ c m}$ & $\mathbf{2 2 . 5} \mathbf{~ c m}$ & $\mathbf{3 0} \mathbf{~ c m}$ & $\mathbf{1 5} \mathbf{~ c m}$ & $\mathbf{2 2 . 5} \mathbf{~ c m}$ & $\mathbf{3 0} \mathbf{~ c m}$ \\
\hline 45 & 13.6 & 13.75 & 14.5 & 12.7 & 13.7 & 14.2 & 12.7 & 13.3 & 14.8 \\
60 & 17.3 & 17.8 & 18.5 & 17.3 & 17.5 & 18.3 & 17.4 & 18.1 & 18.3 \\
75 & 19.5 & 19.9 & 20.5 & 18.4 & 18.7 & 19.5 & 18.8 & 19.4 & 19.8 \\
90 & 23.2 & 24.2 & 25.1 & 23.1 & 23.7 & 24.2 & 22.8 & 23.1 & 23.5 \\
105 & 25.1 & 25.7 & 26.4 & 24.4 & 25.1 & 25.9 & 25.1 & 25.4 & 26.8 \\
120 & 27.8 & 27.7 & 28.2 & 26.4 & 27.1 & 27.7 & 26.8 & 27.4 & 27.8 \\
135 & 30.4 & 30.8 & 31.5 & 29.4 & 30.0 & 30.5 & 30.0 & 31.2 & 31.7 \\
\hline
\end{tabular}

Table 3. Canopy temperature of wheat sown under different row directions during 2012-13.

\begin{tabular}{ccccccc}
\hline \multirow{2}{*}{ DAS } & \multicolumn{2}{c}{ HD 2967 } & \multicolumn{2}{c}{ PBW 550 } & \multicolumn{2}{c}{ PBW 343 } \\
\cline { 2 - 7 } & N-S & E-W & N-S & E-W & N-S & E-W \\
\hline 45 & 11.2 & 12.2 & 10.7 & 11.5 & 10.8 & 11.8 \\
60 & 18.8 & 19.5 & 18.5 & 19.3 & 18.6 & 19.3 \\
75 & 17.4 & 17.8 & 17.2 & 18.1 & 17.2 & 17.7 \\
90 & 22.0 & 23.2 & 21.7 & 22.9 & 21.9 & 23.1 \\
105 & 23.7 & 24.2 & 22.5 & 23.6 & 23.6 & 24.1 \\
120 & 25.1 & 26.2 & 25.9 & 27.2 & 26.4 & 27.9 \\
135 & 30.0 & 31.0 & 28.7 & 30.1 & 29.8 & 30.8 \\
\hline
\end{tabular}

Where, DAS: Days after sowing N-S: North-South

per cent) in case of HD 2967 in E-W row direction followed by PBW 343 (75.0 and 76.0 per cent) and was lower in PBW 550 (74.4 and 75.0 per cent) during 2012-13 and 2013-14 at heading stage. SWR interception was less in N-S row direction as compared to E-W row direction. In HD 2967 mean SWR interception in
E-W: East-West

N-S direction was 74.6 and 75.0 per cent followed by PBW 343 (74.5 and 74.0 per cent) and PBW 550 (73.0 and 73.3 per cent) during 2012-13 and 2013-14. In all the three varieties SWR interception decreased gradually 90 days afterwards as after heading stage as LAI decreased in both row directions. Similarly, Khan et al. 
Table 4. Canopy temperature of wheat sown under different row directions during 2013-14.

\begin{tabular}{ccccccc}
\hline \multirow{2}{*}{ DAS } & \multicolumn{3}{c}{ HD 2967 } & \multicolumn{2}{c}{ PBW 550 } & \multicolumn{3}{c}{ PBW 343 } \\
\cline { 2 - 7 } & N-S & E-W & N-S & E-W & N-S & E-W \\
\hline 45 & 12.7 & 14.1 & 11.6 & 13.3 & 12.1 & 13.8 \\
60 & 21.0 & 22.5 & 20.7 & 22.2 & 20.8 & 22.1 \\
75 & 18.7 & 19.6 & 17.7 & 19.1 & 18.2 & 19.1 \\
90 & 23.2 & 23.9 & 24.5 & 24.9 & 25.1 & 25.8 \\
105 & 26.1 & 27.3 & 24.2 & 24.0 & 24.8 & 24.6 \\
120 & 28.2 & 28.9 & 26.4 & 27.1 & 26.8 & 27.8 \\
135 & 31.0 & 31.7 & 30.6 & 31.0 & 31.0 & 31.4 \\
\hline
\end{tabular}

Where, DAS: Days after sowing $\quad$ N-S: North-South

(2010) observed that accumulated global radiation during vegetative phase of crop showed a positive correlation but during reproductive and grain filling phases they exhibited negative correlation with dry matter production in wheat. O'Connell et al., (2004) also reported similar results. Similarly, Adak and Chakravarty (2012) concluded that radiation penetration at the early crop growth stage was highest and decreases within crop canopy as the leaf area develops. Canopy temperature under different treatments: Canopy temperature is referred as the average temperature of leaves of foliage of crop. Canopy temperature is a useful indicator of plant water status. Plant water status by regulating the vital physiological and morphological characteristics of plants proved to be a useful factor in determining the grain yield.

When there is abundant supply of water and ambient temperature is not very high, the plants would transpire freely without any restriction. As a result cooling of leaves would continue causing low temperature of leaves and thereby reducing the canopy temperature. The canopy temperature was minimum in $15 \mathrm{~cm}$ row spacing in all the three varieties (HD 2967, PBW 550 and PBW 343) followed by $22.5 \mathrm{~cm}$ row spacing and was maximum in $15 \mathrm{~cm}$ row spacing. As in wider spacing due to less plant population transpiration rate was less as compared to narrow $(15 \mathrm{~cm})$ row spacing. Chen et al. (2010) confirmed that with the increase in row spacing the rate of transpiration decreases. Among different varieties canopy temperature did not show much difference. Although canopy temperature was slightly higher in HD 2967 followed by PBW 343 and PBW 550 because plant stand and other characteristics were better under HD 2967.

Variation in canopy temperature at 15 days interval is presented in Tables 1 and 2 in different wheat varieties under different row spacing. During 2012-13, the canopy temperature was low during 75 DAS in all the three varieties under different row spacing because at 75 DAS there was $23.6 \mathrm{~mm}$ rainfall which decreased the mean temperature. Among 2012-13 and 2013-14 there was slight difference in canopy temperature. Any fall or rise in canopy temperature was due to prevailing

\section{E-W: East-West}

weather conditions of that particular period. Yang et al. (2008) reported that leaf area index decreased and canopy openness increased with increased row spacing. Moreover, relative humidity decreased and canopy temperature at each layer increased.

Canopy temperature was recorded at 15 days interval in different wheat varieties under different row direction viz. N-S and E-W during 2012-13 and 2013-14. Among different growth stages canopy temperature was lower during initial stages of crop and was higher at reproductive stage due to less transpiration rate at reproductive stage. Canopy temperature was slightly higher in E-W row direction as compared to N-S row direction as shown in Tables 3 and 4.

Relationship between canopy temperature and dry matter accumulation: Regression analysis was conducted between canopy temperature and dry matter accumulation in wheat sown under different row spacing and row direction. Polynomial equations were found to be best fit in both cases as presented in figs. 3 and 4. Dry matter accumulation invariably showed a high degree of relationship with canopy temperature which indicated that dry matter accumulation is influenced by canopy temperature. Relationship between dry matter accumulation and canopy temperature of wheat sown under different row spacing gave significant $\mathrm{R}^{2}$ value $(0.66)$ which indicated that 66 per cent variability in dry matter accumulation was because of canopy temperature of wheat varieties sown under different row spacing. Similarly, dry matter accumulation and canopy temperature of wheat sown under different row direction gave significant $\mathrm{R}^{2}$ value $(0.69)$ which indicated that 69 per cent variability in dry matter accumulation was because of canopy temperature of crop. According to Kaur et al. (2002) canopy temperature has a significant effect on wheat dry matter accumulation and grain yield so there is ample scope that mid-day canopy temperature can be used as a possible tool for monitoring plant water status and grain yield prediction.

\section{Conclusion}

Agronomic manipulations viz. change in row spacing and sowing of wheat in different row direction 
influenced microclimate of wheat. Solar radiation interception and canopy temperature were influenced by agronomic manipulations and further influenced dry matter accumulation of wheat. Dry matter accumulation is the important component of grain yield. Canopy temperature can be used as important tool to predict dry matter accumulation of wheat.

\section{REFERENCES}

Adak, T. and Chakravarty, N. V. K. (2012). Seasonal changes in radiation penetration within mustard crop canopy. J. Soil Water Cons., 11:73-79

Anonymous (2014) Department of Agriculture, Punjab. Chandigarh.

Braun, H. J., Atlin, G. and Payne, T. (2010). Multi location testing as a tool to identify plant response to global climate change. In Reynolds MP (Eds) Climate change and crop production. Wallingford, UK:CABI Publishers.pp: $115-38$

Carretero, R., Serrago, R. A., Bancal, M. O., Perello, A. E. and Miralles, D. J. (2010). Absorbed radiation and radiation use efficiency as affected by foliar diseases in relation to their vertical position into the canopy in wheat. Field Crop Res., 116: 184-195

Charles-Edwards, D. A. (1981). Physiological determinants of crop growth. Academic Press. Sydney, pp:158.

Chen, Suyin., Xiying, Zhang., Hongyong, Sun.,Tusheng, Ren. and Yanmei, Wang. (2010). Effects of winter wheat row spacing on evapotranpsiration, grain yield and water use efficiency. Agric. Water Mgt., 97:1126-32

Hundal, S. S. (2004). Climatic changes and their impact on crop productivity vis-à-vis mitigation and adaptation strategies, Proc. Workshop on Sustainable Agriculture Problems and Prospects. pp 148-53. Punjab Agricultural University, Ludhiana, India

Jarwal, S. D. and Singh, P. (1990). Influence of planting geometry on photosynethically active radiation interception and dry matter production relationships in pearlmillet. Biomass, 21: 273-284
Joshi, A. K., Mishra, B., Chatrath, R., Ortiz Ferrara, G. and Singh, R. P. (2007). Wheat improvement in India: Present status, emerging challenges and future prospects. Euphytica, 157: 457-464

Kaur, K., Mathauda, S.S. and Bains, G.S. (2002). Prediction of grain yield from canopy temperature based indices. $J$. Res. Punjab Agric. Univ., 39: 346-353

Khan, H. R., Paull, J. G., Siddique, K. H. M., Stoddard, F. L. (2010). Faba bean breeding for drought-affected environments- A physiological and agronomic perspective. Field Crops Res., 115: 279-286

Kingra, P. K., Mahey, R. K., Gill, K. K., Mukherjee, J. and Bal, S. K. (2010). Prediction of grain yield of wheat using canopy temperature based indices. J. Agromet., 12: 61-63

Kumar, M., Raghuwanshi, N. S., Singh, R., Wallender, W. W. and Pruitt, W. O. (2002). Estimating evapotranspiration using artificial neural network. J. Irr. Drain., 128: 224-233

O'Connell, M. G., O'Leary, G. J., Whitfield, D. M. and Connor, D. J. (2004). Interception of photosynthetically active radiation and radiation-use efficiency of wheat, field pea and mustard in a semi-arid environment. Field Crops Res., 85: 111-124

Reddy, S. R. (2006). Agronomy of field crops, pp: 143-88. Kalyani Publishers.

Tompkins, D. K., Fowler, D. B., and Wright, A. R. (1993). Influence of agronomic practices on canopy microclimate and septoria development in no-till winter wheat produced in the Parkland region of Saskatchewan. Can. J. Plant Sci., 73: 331-44.

Virmani, S. M. (1994) Climatic research characterization in stressed tropical environment, constraints and opportunities for sustainable agriculture. Proc Intern. Symp. on agroclimatology and sustainable agriculture in stressed environments. Oxford IBH publishing Co Pvt Ltd, New Delhi.pp.149-60.

Yang, Wen. Ping., Guo, Tian. Cai. and Liu, Sheng. Bo. (2008) Effects of row spacing in winter wheat on canopy structure and microclimate in later growth stages. Chinese J. Pl. Eco., 32: 485-490. 